\title{
Can claims for 'wrongful life' be justified?
}

Gary E Jones and Clifton Perry Department of Philosophy, University of San Diego and Auburn University, Auburn, Alabama respectively

\section{Editor's note}

The authors reject arguments by Professor Foseph Fletcher (author of Situation Ethics) that in some circumstances parents may be held responsible for producing genetically defective offspring, but offer arguments of their own for the same conclusion. Their arguments could, they suggest, justify 'wrongful life' claims by the genetically defective infant against the mother.

While researching this paper both authors were postdoctoral fellows in medical ethics in the Program on Human Values and Ethics at the University of Tennessee Center for the Health Sciences.

In a well-known essay (1), Joseph Fletcher has argued that compulsory controls on human reproduction are ethically justified:

Trying to be responsible we have to calculate. We issue drivers' licences, for example, even though the cars of some will become lethal weapons; it is the price we pay for motor transport. If we could tell which applicants for a licence would be killers we would not license them. It used to be that we had no way of knowing which couples were carrying a common gene defect or which pregnancies were positive for it. But now we can know; we have lost that excuse for taking genetic risks. To go right ahead with coital reproduction in many couples' cases is like walking down a line of children blindfolded and deliberately maiming every fourth child. It is cruel and insane to deprive normal but disadvantaged children of the care we could give them with the $\$ 1,500,000,000$ we spend in public costs for preventable retardates $(2)$.

While we may applaud Fletcher's motives and may even agree with aspects of his conclusion, many portions of his argument are suspect. First, Fletcher's argument about licence applicants needs scrutiny. Fletcher is clearly not only concerned with 'killer'

\section{Key words}

Genetic defect; genetic screening; wrongful life; human reproduction; rights; privileges; medical ethics; eugenics. genetic states such as anencephaly and perhaps TaySachs disease and other fatal genetically transmittable disorders. His reference to the financial burden of maintaining 'retardates' indicates that he does not wish thus to restrict the scope of his argument. If, however, he is to include non-fatal genetic defects in his argument then the relevant analogue is not a killer driver but a killer-or-maimer driver. Furthermore, to tighten the analogy still further he should be concerned with our being able to tell what the probabilities are of a licence applicant being a killer-or-maimer rather than with certain knowledge about this. Thus Fletcher's argument, if it is to offer a real analogy with carriers of fatal and/or non-fatal genetic disorders should be: 'If we could tell which applicants for a licence would have a high probability of being killers or maimers we would not license them'. That, however, is not an accurate claim, for many drivers convicted of negligent homicide are allowed to retain their driving privileges. This fact has recently led to the formation of special interest groups whose sole purpose is to cause the enactment of stronger legislation against drunk drivers (3). What these facts suggest is that the duty to prevent harm to others is tempered by respect for the freedom of the individual, even if risk of harm to others is caused in the exercise of that freedom. The relevant point in the context of human reproduction would be that there is a presumption of noninterference with the reproductive lives of individuals. It could be maintained that the possibility of a defective child is the 'price' we pay for the freedom we enjoy.

Fletcher's analogy involving the issuing of drivers' licences is, however, more fundamentally flawed. A licence to drive is unquestionably a privilege (4) or benefit requiring special qualification; one has not merely to be a competent citizen but also to take a series of tests. And in the US a portion of the tests must be retaken every few years. Given serious and frequent transgressions of the law, the driving privilege can be revoked. On the other hand, unless Fletcher is assuming what he is attempting to prove, procreation is not normally understood to be a privilege in the same sense. Any competent adult may procreate (5). Even if one opts for marriage and a blood test for syphilis is required, no one can 'fail' the test. Persons suffering from syphilis may still have children. Therefore the 
right to procreate seems more like a basic right such as the right to vote, the right to free speech. the right to legal counsel, etc, than merely an acknowledged privilege such as driving. Of course rights are not generally considered to be unconditional. One can legitimately exercise one's rights only to the extent that they do not infringe on others' rights. Fletcher attempts to capture this aspect of rights be claiming that rights are really 'only privileges' (2). It is not clear, however, that this contention clarifies matters. There could still be a distinction between rights and privileges even if rights are not unconditional. Rights could be those 'powers' that any citizen of a certain age automatically receives, without having to be 'licensed' or take periodic tests. These rights can be forfeited by transgressions of the agent but no special qualification is needed to obtain them. 'Privileges' or 'benefits' on the other hand are not automatically due to each citizen; not only can they be forfeited, but one must initially qualify for the privilege. Licensing of qualified applicants indicates that they have demonstrated capabilities that the ordinary citizen is not required to demonstrate.

If the above remarks are plausible, it seems that, pace Fletcher, there remains a distinction between rights and privileges and that Fletcher has not proven that the choice of procreation is a privilege. Finally, it seems reasonable to claim that the choice of procreation, at present at least, has the status of a right rather than a privilege.

Moreover, care must be taken in describing the decision to procreate. When a couple is at risk the result of such a decision may be a defective infant. Fletcher likens such a decision to the 'deliberate maiming' of a (presumably normal) child. It is surely doubtful, however, that most parents intend to have defective offspring as the term 'deliberate' suggests. They are rather deciding to have children in spite of the risk, though in certain cases this may be ill-advised. In addition, Fletcher's analogy is misleading in another fundamental way. To walk down a line of normal children, deliberately maiming every fourth one, suggests that were it not for this action the children would be of normal health. This suggests that except for the negligent parents' intervention, the affected children would have enjoyed a healthy life. But clearly one of the most troublesome aspects of severe birth defects is that in most cases the defect cannot be 'separated' from the victim. If the victim is not born in that defective manner, (s)he will not exist at all. Alternative modes of procreation such as egg transfer from a non-carrier donor to a carrier's womb avoid the conception of a defective fetus at the expense of avoiding the existence of that particular fetus entirely. Thus it is not the case that parents who are carriers of defective genes 'maim' pre-existing, normal children by having defective offspring. Coming into the world as defective infants would be the only way in which these particular individuals would ever exist at all.

It might nonetheless be contended that it is a disservice or even an injustice to these individuals to bring them into the world at all, even if nonexistence is the only alternative. Since Fletcher has not succeeded in demonstrating that the choice of procreation is a privilege such as driving, an alternative basis for such a claim is needed. In the discussion of Fletcher's views it was suggested that the choice of procreation was more plausibly understood as a right than a privilege. Even so, it was noted that rights are not unconditional. Generally speaking, people may not exercise their rights if that exercise violates the rights of others. This aspect of rights is captured in the legal system in both the criminal and civil codes. If a person unintentionally harms another, he may be subject to either criminal or civil sanctions, or both. Very serious, flagrantly negligent actions which involve less than benign motives and result in tragic consequences can be the subject of criminal neglect proceedings. Civil suits or 'torts' cover most cases where one citizen, though benignly motivated, through neglect harms another. It would seem that if parents who are carriers for defective genes are to be held responsible for causing the birth of defective children, it would be under the rubric of civil suits (6) and that is the assumption which we shall now pursue.

\section{II}

Given our current medical technology and knowledge of genetics, certain anomalies can be detected in utero, for example, Tay-Sachs, Down's syndrome, spina bifida, anencephaly, etc; and certain anomalies are known to be hereditary, for example, polycystic kidney disease. Furthermore, given knowledge that the fetus is actually afflicted or is likely to be afflicted, appropriate action is available to circumvent the anomaly, for example, therapeutic abortion, contraception or sterilisation. Finally, parents, by virtue of the special relationship which obtains between the physician and the patient, have a right to information that they are 'at risk' or have a fetus which has been determined to be defective, and they have a right to information on the availability of procedures designed to circumvent the birth of a defective child (7).

If the prospective parents are found to be at risk or to have a defective fetus but are not properly informed, the medical team whose responsibility it is to inform the parents may be sued for being remiss in their duties to the parents and for allowing harm to befall the defective child (8). With respect to harm caused to the parents, the medical team may be sued for the cost of raising a defective child in excess of the cost of raising a normal child for the same period, and also for the emotional stress involved (9). Compensation for the child, however, would have to be for suffering an affliction which could only have been eliminated through the child's nonexistence.

Such 'wrongful life' suits, it might be claimed, are fatuous (10). In order to receive money compensation in a suit for damages based upon negligence it must be demonstrated that one is worse off because of the negligent behaviour (ie worse off existing in a defective state 
as a result of negligence) than one would have been in the absence of such behaviour (ie not existing at all). But surely, it is argued, it is impossible to demonstrate that existence in a defective state is a greater harm than nonexistence. Since we do not know the harm of nonexistence in comparison to the harm experienced by this defective child, we have no way of concluding that the affected child has, in fact, been damaged. Since the burden of the suit rests with the plaintiff and damage cannot be shown, there are no grounds for the suit. On the other hand if there were some way of reasoning that the child would have been better off not existing than existing in his condition, then grounds for suing on behalf of the child would at least be established. Is it really clear that such comparisons can not be made? It would seem that comparison of the relative harms of existence and nonexistence occurs every day with cases of patients who will die unless they receive medical life support. If a patient's life might be prolonged but not improved and the patient's present state seems intolerable, then palliative care may become the only medical concern and life-prolonging treatment may be withheld or discontinued. In such cases it is presumably decided that prolonging the patient's life would be more harmful than not prolonging it. This at least seems like a comparison between the harm of existence in a particular state and the harm of nonexistence. If this is indeed correct, then since we make such comparisons with respect to patients with certain medically determined anomalies, why should it be considered impossible to make such comparisons in connection with 'wrongful life' suits?

One argument might be that when removing or withholding life support, the patient's consent is often obtained and consent could not be obtained from the genetically defective fetus. However, we also remove life support from patients who are no longer sentient and have not expressed any previous wish to be removed from such support (11). Although desirable, consent is not necessary either for removing life support or for making the comparison between the harms of existence and nonexistence.

If comparison between the harms of impaired existence and of nonexistence is indeed intelligible, and justifiable then it becomes clear that a mother might be held responsible for 'wrongful life'. For instance, if a 40-year-old woman is found, through amniocentesis, to be carrying a fetus afflicted with spina bifida, but decides to give birth anyway, then the defective child would not have suffered his existence were it not for the mother's behaviour. In such a case, the mother could become a defendant in a 'wrongful life' suit (12). Such a 'wrongful life' suit would be based on the claim that the genetically defective child had been harmed through the behaviour of others and that this harm could have been prevented. The physician would not be responsible if he had fulfilled his role in preventing such harm by presenting relevant information and performing tests and procedures where appropriate and requested. Then it is the parents and specifically the mother who can prevent harm by acting on the information that the pregnancy is at risk and thus be held responsible for the results of not acting to prevent such harm. This argument does not, of course, justify Fletcher's compulsory control of reproduction - but it does show how parents may be held responsible for the 'wrongful life' of their genetically damaged offspring.

In conclusion, we have argued that Fletcher's argument purporting to demonstrate parental responsibility for having defective offspring is defective. His analogy with the privilege of driving was found to be suspect on several counts. Nonetheless, we have argued that such responsibility can be demonstrated on the basis of ordinary thinking underlying civil laws regarding negligence.

\section{References and notes}

(1) Fletcher J. Costs and benefits, rights and regulation, and screening. In: Mappes T, Zembaty J, eds. Biomedical ethics. New York: McGraw-Hill Publishing Co, 1981: $475-478$.

(2) See reference (1): 476

(3) The organisation in California is Mothers Against Drunk Drivers (MAD).

(4) The California drivers handbook, for instance, is emphatic on this point.

(5) In 1942, the United States Supreme Court decided that the right to procreate was a basic constitutional right that even incompetent persons enjoyed. Annas F G. Sterilization of the mentally retarded: a decision for the courts. Hastings center report 1981; Aug 11, 4: 18-20.

(6) Returning to the analogy of drivers of automobiles, it can be said that negligent drivers can be sued by their victims even if they retain their driving privileges and hence, in a sense, their freedom to be negligent. In this connection consider the interesting argument presented by Lafollette H. Licensing parents. Philosophy and public affairs 1980; 9, 2: 182-197.

(7) For an interesting comment on mandatory genetic screening see Bayles $M$. Catch-22: paternalism and mandatory genetic screening. In: Robison $W$ L, Pritchard M S, eds. Medical responsibility. Clifton, New Jersey, Humana Press, 1979: 29-42. According to Bayles, one may be treated paternalistically and forced to be genetically screened so that one might be fully informed when deciding whether or not to have children.

(8) See Becker v Schwartz and Park v Chessin, 386 NW 2d 807 (New York, 1978). Gildiner v Thomas Jefferson University Hospital, 451 F. Su-p. 692 (ED PA 1978) Berman v Allan, 404 A 2d 8 (New Jersey, 1979). Speck v Finegold, 408 A 2d 496, 500 (PA Super 1979) and most recently Curlender v Bio-Science Laboratories, 165 California Reporter 477 (Ct App 2d Dist Div 1, 1980).

(9) This was noted in Becker $v$ Schwartz. For instance, according to the Center for Disease Control, the current cost of medical care for a spina bifida child's first 20 years is $\$ 16,800$ while it is only $\$ 2,400$ for normal children. See Kolata G B. Mass Screening for neural tube defects. Hastings Center Report 1980; Dec 6, 10: 8-10.

(Continued on page 174) 
(10) Alnot M O, Parseval G de, Granet Ph, Da Lage G. Sperme, don, contre don. Concours médical 1982; 104: 2915-2918.

(11) Guillon C, Le Bonniec Y. Suicide mode d'emploi. Histoire, technique, actualités. Paris: Editions Alain Moreau, 1982.

(12) Rouzioux J M. Les essais des nouveaux médicaments chez l'homme. Problemes juridiques et éthiques. Paris: Masson, 1978.

(13) Code de déontologie médicale. Décret n ${ }^{0} 79-506$ du Juin 28 1979. Fournal officiel 1979 Jun 30.

(14) Villey R. Déontologie médicale. Paris: Editions Masson, 1982.

(15) Règles de déontologie applicables aux médecins et aux pharmaciens chimistes des armées. Décret N0 81-60 du Janvier 16 1981. Fournal officiel 1981 Jan 28.

(16) La déontologie médicale à l'hopital. Paris: Bulletin de l'Ordre des Médecins. 1982; 353-398.
(17) L'AMIP présente une 'Charte du médecin de l'industrie pharmaceutique'. Fonctions, responsabilités et devoirs. Concours médical 1978; 100: 1580-1582.

(18) Ethique et médecin de l'industrie pharmaceutique. Consultation Delphi sur un panel d'experts. Nancy: Bulletin de l'A baclub 1979; 7-8: 6-19.

(19) Code des bonnes pratiques d'information. Paris: Bulletin de l'Ordre des Pharmaciens 1982; 253: 1-35.

(20) Moles A. Pour une révision du serment d'Hippocrate. Prospective et sante 1979; 12: 9-18.

(21) Moles A. A new medical oath. New England journal of medicine 1982; 307: 761.

(22) En lisant le code de déontologie médicale. Paris: Bulletin de l'Ordre des Médecins 1982; 401-410.

(23) Regnier F. La médecine: pour ou contre les Hommes? Paris: Editions Pierre Belfond, 1976.

(Continued from page 164)

(10) See Annas G. Righting the wrong of 'wrongful life'. Hastings Center report 1981; Feb 1, 11: 8-9.

(11) Consider the case of removal of extraordinary medical technology in the case of Karen Ann Quinlan. The Supreme Court of New Jersey, March 31, 1976, presented by Chief Justice Hughes reprinted in part in Munson R, ed. Intervention and reflection. Belmont, California: Wadsworth Publishing Company, 1979: 135140. See also Eichner v Dillon, 426 New York State. 2nd
517 (Sup Ct, App Div 2d Dept, 1980) and In the matter of Earle N Spring 405 NE 2d -15 (Massachusetts 1980). See also Superintendent of Belchertown State School v Saikewicz, 370 NE 2d 417 (Massachusetts 1977).

(12) This was noted in Curlender v Bio-Science Laboratories. According to Kolata G B, only three of 70 couples reported decided to give birth to a child determined to have spina bifida in utero. See reference (9) Mass screening for neural tube defects. 